Litwińskiego pominięte. Gdy na s. 84 pojawia się w tekście nazwisko płk. Louisa Fauryego, który nie jest powszechnie znany, autor nie wyjaśnia, kim ten człowiek był. Jest to niezrozumiałe, jeżeli na przykład weźmiemy pod uwagę fakt, że na s. 31 można przeczytać biogram gen. Kazimierza Sosnkowskiego, a na kolejnej biogram gen. Władysława Sikorskiego. Oczywiście można uznać, że Faury nie odgrywał jakiejś istotnej roli w życiu Zamorskiego, dlatego jego biogram nie został w publikacji przytoczony. Niemniej podobną do Fauryego rolę w życiorysie "granatowego generała” odegrał Juliusz Malczewski. Jego biogram został jednak sporządzony na s. 20 omawianego dzieła. Ponadto na s. 327 autor napisał, że Zamorski, wyjeżdżając z kraju w 1939 r., pozostawił m.in. „mieszkanie na al. Schucha”. Powinno być ul. Szucha. Być może jest to jednak zwykły błąd redakcyjny.

W konkluzji chciałbym zaznaczyć, że w mojej ocenie praca Roberta Litwińskiego dotycząca gen. Kordiana Józefa Zamorskiego jest książką ważną i potrzebną. Przede wszystkim wypełnia lukę w historiografii. Oparta jest również na solidnej kwerendzie źródłowej. Wątpliwości nie budzi również większość wniosków wyciąganych przez autora. Co więcej, Litwiński bardzo sprawnie operuje językiem polskim, przez co jego opracowanie czyta się bardzo dobrze. Ponadto autor ubogacił treść publikacji o dość pokaźny materiał ilustracyjny. Oczywiście - co wykazałem w niniejszej recenzji - są także elementy dyskusyjne. Nie wpływają one jednak na merytoryczną jakość pracy. Wydaje mi się zatem, że warto na książkę Litwińskiego spojrzeć życzliwym okiem.

Paweł Sztama

DOI: 10.32089/WBH.phw.2019.2(268).0009 orcid.org/0000-0002-1268-0432

\title{
Some remarks on Robert Litwiński’s book Kordian Józef Zamorski - the „blue” general
}

Biographical research is one of the most difficult historiographical forms ${ }^{1}$, or perhaps even the most challenging one. This is mainly due to methodological and source-related issues. A historian who prepares a biography must not only investigate thoroughly into the life of the protagonist of the book, but should also get significant insight into the times when

\footnotetext{
https://www.polskieradio.pl/8/3664/Artykul/1210511,Profesor-Antoni-Dudek-napisalem -biografie-potwora-bo-mnie-zainteresowal (accessed on 25.02.2019).
} 
they lived. This makes it necessary for the author to read through a huge pile of literature concerning different historical periods. Moreover, when the protagonist of the biography was active in various fields and worked in several institutions, the historian is obliged to find and get to know a whole range of important documents, thanks to which he will be able to depict the life of the person he is interested in. It is therefore important to carry out research and source queries in numerous institutions, such as the Archiwum Akt Nowych (Archive of New Files), but also in those that are sometimes difficult to reach. These include, for example, school, university, company and private archives. Furthermore, the researcher not only has to describe the person's activity in the subsequent periods of their life, but also - according to the standards in contemporary historiography - he or she should try to look into the soul of the protagonist and try to find out, for instance, what motivated their life choices, what opinions they had on various events, etc.

This is approximately the trouble taken by Robert Litwiński, who decided to familiarize his readers with the biography of an interesting but rather poorly known figure, i.e. General Kordian Józef Zamorski. The author, who specializes in the history of various types of police institutions operating on the territory of Poland in the 20th century, as well as in the internal politics of the Second Polish Republic ${ }^{2}$, thus broke out of the scheme imposed, probably unconsciously, by a group of Polish historians involved in the study of the history of Poland in the first half of the 20th century. Those historians were mainly engaged in getting to know the biographies of high-ranking Polish officers who devoted most of their adult lives to military or public service. Thanks to the effort made by Litwiński, the reader can take the opportunity to become acquainted with the biography of the last Commander-in-Chief of the Polish State Police before the outbreak of World War II.

The book consists of the Introduction, four core chapters, as well as the Conclusion, List of Sources and Studies, List of Abbreviations, and Personal Index. The layout adopted by the author has a chronological and problematic order, which in this case is the most appropriate solution. In a transparent study, Litwiński tries to show the life and activity of the "blue general”, as he calls Kordian Zamorski.

The first chapter is entitled Towards Independent Poland. The author divided it into four smaller subchapters: Childhood and School Years, The Beginnings of Independence Activity, In Cracow, The Great War. Litwiński depicted the youth of Zamorski from his birth in 1890 to the end of World War I. From this chapter the reader shall learn, among others, where and

2 https://www.umcs.pl/pl/addres-book-employee,1583,pl.html (accessed on 25.02.2019). 
what kind of family Zamorski came from, where he studied, what his independence activities looked like or how his fate unfolded during the first global military conflict.

The second chapter entitled In the Army of the Second Polish Republic was divided into the following subchapters: Fight for Borders, Years of Peace, In the General Staff of the Polish Army, On the Political Situation in the Country. The time frame of this part is determined by the years 1918-1935. At the end of 1918 Zamorski joined the ranks of the reviving Polish Army, and at the beginning of 1935 he was transferred from the army to the so-called inactive state. The second chapter describes the general's activity in the Polish army, such as serving as Chief of Staff of the 3rd Corps District Command in Grodno, Chief of 1st Department of the General (Main) Staff (GS) Staff, and finally his activity as the Second Deputy Chief of GS of the Polish Army. Moreover, in the last subchapter of this part, the author presented Zamorski's observations on the general, personnel and technical policy pursued by the Sanation in the Polish Army in the 1930s.

The next chapter is entitled Head of the Police. Its content consists of three subchapters: Commander-in-Chief of the State Police, New Subordinates and Towards the Professionalization of the Corps. Litwiński presented not only the actual activities of Zamorski, but also certain ideas, reforms and assumptions that Zamorski introduced or intended to introduce to the institution he was in charge of.

The book closes with chapter four, entitled Exile and Emigration. In four subchapters: September 1939, In Romania, In the Middle East, In Great Britain, the complicated fate of the blue general was shown from the outbreak of World War II, through internment in Romania, a stay in the Middle East, departure to England, and until his death in 1983.

Next to the clarity of the study, another positive aspect of this publication is the bibliography presented at the end of the book. The author has reached a great many sources and documents, which were scattered in nineteen archives. Among the institutions that Litwiński visited and queried are, among others, the Archives of the Academy of Fine Arts in Cracow, the Archive of New Files in Warsaw, the Library of the Ossoliński National Institute in Wrocław, the Central Military Archive of Military Historical Bureau in Warsaw-Rembertów, as well as Polish archival institutions operating abroad, such as the Józef Piłsudski Institute in New York or the General Sikorski Polish Institute and Museum in London. In addition, Litwiński used the documentation of the Russian State Military Archive in Moscow and worked on sources kept in such institutions as the state archives in Bydgoszcz, Katowice, Lublin and Warsaw or the Police Museum in Warsaw.

Additionally, the author used a multitude of important documents already printed, reached dozens of diaries and memoirs, reviewed the information-rich 
press of the era and drew on several hundred studies. The number of articles and books used would probably have been much greater if in the biographical footnotes Litwiński had provided the titles of the studies he had used to present a given character. Moreover, the historian from Lublin missed several important studies concerning various events described in the book. For example, the classic work on World War I by Jan Dąbrowski ${ }^{3}$ or the monumental work edited by Piotr Stawecki entitled Zarys $z$ dziejów wojskowości polskiej w latach 1864-1939 (Outline of Polish Military History in 1864-1939) are nowhere to be found. These deficiencies, however, in no way diminish the effort that the author put into his work on Zamorski's biography.

This pile of documents and literature, mentioned above, was used by Litwiński to prepare the first and basically complete biography of the general. The author has thus filled a gap in Polish historiography. So far, few have been interested in Zamorski. Why was that? It is hard to find an answer to this question. After all, he held important, although not leading positions in the military structures of the army of the Second Polish Republic, and was the last Commander-in Chief of the State Police before the outbreak of World War II. Of course, the rank of a person should not be an exclusive decisive reason for the preparation of their biography ${ }^{4}$. Nevertheless, it is often the most important factor. In this case, it should be remembered that the State Police commanded by the general played an important role in maintaining public order in pre-war Poland, and on its shoulders was even the fight against communists operating on the territory of the Second Polish Republic. Having this in mind, a biography of the man who for a few years had a significant impact on its functioning should have already been prepared some time ago.

For the aforementioned reason, Zamorski's biography is undoubtedly an important and innovative book. However, from the very beginning the author set himself a difficult and courageous task. On page 12, quoting Aleksander Gieysztor, he wrote: „Today's biographical research sets itself quite high standards: from showing the protagonist in a novel in the social context and the course of his or her fate in the community, to drawing on contemporary psychology, and with its help to trying to understand the psyche". The author should only be applauded for such an approach. However, the assumptions are one thing, and the outcome is another.

\footnotetext{
3 J. Dąbrowski, Wielka wojna 1914-1918. Na podstawie najnowszych źródeł [The Great War of 1914-1918. Based on the latest sources], parts 1-4, Poznań 2000-2001.

4 V.L. Zaszkilniak, Trudności biograficznego badania albo jak za drzewami zobaczyć las? [Difficulties in biographical research or how to see forest for the trees?]; Biografistyka we wspótczesnych badaniach historycznych. Teoria i praktyka [Biography in the contemporary historical research. Theory and practice], ed. J. Kolbuszewska, R. Stobiecki, Łódź 2017, pp. 28-29.
} 
The biography of Kordian Zamorski is most of all a work in which the author tried to thoroughly and conscientiously reconstruct the individual parts of the protagonist's life. The above-mentioned fragment of the review concerning the bibliography of the book may prove that was a strenuous and meticulous task. In addition, Zamorski was an interesting personality with quite broad mental horizons, and in his life he held many important positions. Therefore, it was not easy to reconstruct his biography.

Litwiński managed to construct a solid framework for his book. The reader will easily learn a lot of important information about the particular periods of Kordian Zamorski's life. The author has reconstructed, among others, the beginnings of the protagonist's conspiratorial work, as well as the course of his studies at the Academy of Fine Arts in Cracow. Zamorski was actually a promising artist. Nothing came out of his youthful dreams, however, and the general pursued his passion in his time off duty. As Litwiński noted, decent works of art were created at that time by his protagonist, such as his wife's portrait painted in 1936, the reproduction of which was placed at the end of the book.

In the subsequent parts of the publication, the author recreated $\mathrm{Za}$ morski's rich biography piece by piece. And so, Litwiński carried his study through the actions of World War I, the Polish-Ukrainian War and the Polish-Soviet War. Then he described the general's activities on various command positions in the Polish Army. Several dozen pages are devoted to his service in the GS, where Zamorski held the position of the Head of First Department, as well as Second Deputy Chief of GS. From these excerpts we learn about his competences, views and opinions at that time. Thanks to the diaries written down by Zamorski over the years, the author was able to recreate the problems that the general faced back then. As it turns out, the general had a rather critical attitude towards many people from Marshal Józef Piłsudski’s entourage, and he had mixed feelings about the Marshal himself from a certain point on. The author was able to use it efficiently and in many fragments of the book he let Zamorski speak, quoting him. Thanks to the quotations, the reader learns that despite the declared loyalty of senior officers of the Polish Army to Piłsudski, there were some, such as Zamorski, who were able to look at him quite critically. Not every decision of the General Inspector of the Armed Forces was to the general's liking and he meticulously noted it.

Having read the book, I had the impression that Litwiński had a lot of respect and fondness for the protagonist of his publication. At the same time, thanks to this biography, I can say that I have not developed such feelings for Zamorski myself. I consider him to be a rather ambiguous character. On the one hand, he was a very clever man, a lover of art with a clear literary talent, which he used for example to write his diary. He was also a skillful soldier and 
organizer, who tried to perform his duties meticulously and conscientiously. On the other hand, especially after 1935, he became more and more displeased, which seems to have turned into resentfulness and grumbling later on. This was largely due to the fact that the decision-making bodies of the Polish state disconnected him from important functions, and later did not intend to use his talents and skills. As a result, he drew various accusations towards Marshal Piłsudski, Marshal Edward Śmigły-Rydz, but also Prime Minister Władysław Sikorski and his immediate entourage, as well as other officials and military men, and later also emigration circles. At some point there was probably no decision-making group against which Zamorski would not hold a grudge. Litwiński's book perfectly illustrates this problem.

Nevertheless, in line with one of the main principles of the historical research, the author does not treat the sources selectively and can look critically at the protagonist of his work. The opinions of people who knew Zamorski and spoke about him in different ways contributed to this. There are not many of them in the publication, but the author did include them in specific contexts and situations.

When in January 1935 the general was dismissed from the Main Staff, he was put at the disposal of the Minister of the Interior, who in turn appointed him Commander-in-Chief of the State Police. The author devoted 78 pages of his publication to this part of Zamorski's biography. He described, among others, the reasons why he took up this position, as well as his views, which were apparently quite critical of the activity and functioning of the State Police. Litwiński also explained what his professional activity at that time was like, who his closest associates were, as well as what changes he tried to introduce in the police and what exactly resulted from them. He also described his contacts with the German police and his acquaintanceship with the infamous SS commander Heinrich Himmler. Unfortunately, in this fragment I missed a few elements concerning the actual functioning of the State Police. For example, I would like to read about its greatest operational successes and failures, about the fight against the communist movement or about the attitude of the State Police and Zamorski himself towards the anti-Semitic events that took place, for example, in Lwów (today Lviv) in the 1930s.

What is more, I have an impression that sometimes Litwiński too delicately touches on the times and events which constituted the background of Kordian Zamorski's life. Historians often struggle to find the right proportions when they attempt to capture this background. In this book, this context has been presented only marginally. Of course, I do not accuse the author of not expanding his publication to monstrous sizes and, for example, not describing the history of World War II. This would be clearly absurd. Nevertheless, I believe that certain things should be shown. The book contains information, for example, about the detention of Polish MPs in 
1930, but there are no passages on the May Coup, for example. Moreover, the author does not refer at all to Piłsudski's death. It is not even about how Zamorski perceived this event, but the fact that the State Police probably secured this great ceremony. I would therefore like to read what the general's work looked like at that time. The same happens with the death of Sikorski, whom the general criticized quite strongly. What is more, nowhere to be found in the publication are fragments concerning the Polish conspiracy operating during the World War II, and the author does not even give the end date of this conflict. Detailed information on the Independent Carpathian Rifle Brigade is also missing. After all, Zamorski was responsible for the Reserve Centre of this unit. It would be worthwhile to write what kind of unit it was, how it found itself in Africa and the Middle East and in what battles it participated. On the other hand, Litwiński wrote about Zamorski’s opinion on the possible outbreak of World War III and the situation of Poland after 1945.

It was precisely this kind of elements - opinions and observations of the general - that were missing in some parts of the text. Of course, it is difficult to speak for sources that do not exist. This was probably the case here. It seems, however, that the author could have at least concluded that due to the lack of documentation he was unable to write anything on the issue or try to make some hypotheses. He did so e.g. on page 281, when he referred to Zamorski's intentions, who in 1940 was considering sending his wife and sons to the country occupied by the Germans and Soviets: Could Zamorski have counted that his name, if only because of his pre-war contacts with Heinrich Himmler or Kurt Daluege, would save his family from repression in the country? At the present stage of research it is difficult to make a definite statement about it, but we cannot exclude such a possibility.

Having read Robert Litwiński's book, I started having doubts about its title, and specifically about the second part - the „blue general”. Zamorski began his career at the end of 1918, and it came to an end in the middle of 1942. During this period he held a number of military functions, including the position of the Second Deputy Chief of GS of the Polish Army, and in the years 1935-1939 he was the Commander-in-Chief of the State Police. It is not a long period of time, considering his whole career. Moreover, as we learn from the book, Zamorski considered himself a soldier most of his professional life. What is more, the term blue is more associated with the so-called blue police, operating in the General Government under the auspices of the German occupier. Regarding the latter, the author explains on page 10 that during the Second Polish Republic the term blue did not have any negative associations. Nevertheless, I believe that from today's perspective, this term carries with it clearly bad connotations. Taking into account all of the above, I believe that such a title would be more appropriate to 
Zamorski's predecessor as Commander-in-Chief of the State Police Janusz Jagrym-Maleszewski, who held this position in the years 1926-1935.

Furthermore, some extended explanations and considerations are sometimes missing in the content of the book. For example, on page 74 the author states that in spring 1920 Zamorski was the Chief of the 1st Department of Area Command Staff of the Polish Army in Ukraine and Deputy Chief of Staff of Polish Military Field Office operating by the government of the Ukrainian People's Republic. Then, without any commentary, it is stated that at the beginning of August 1920 he was put at the disposal of the Supreme Command of the Polish Army. Why did this happen? The author does not explain this in the text. Perhaps this was due to the lack of adequate sources, but such nuances should nevertheless be discussed.

Minor inaccuracies and errors can also be found in the text. In the biographical footnotes, the author tried to explain the biographies of the vast majority of people coming up in the book. Among them were officers, politicians and soldiers. It happened, however, that the profiles of some people were omitted by Litwiński. When the name of Colonel Louis Faury, who is not widely known, appears on page 84 , the author does not explain who this man was. This is incomprehensible if we consider the fact that e.g. on page 31 we can read the biographical profile of General Kazimierz Sosnkowski, and on the following page the profile of General Władysław Sikorski. Of course, one can argue that Faury did not play any significant role in Zamorski's life and thus a note on him did not appear in the publication. Nevertheless, the role of Juliusz Malczewski in the life of the blue general was similar to Faury's, and his biographical profile is available on page 20 of the book. Moreover, on page 327 the author wrote that upon leaving Poland in 1939, Zamorski left behind, among others, an apartment on Schucha Avenue. It should be Szucha Street. Perhaps, however, this is a simple typographical error.

In conclusion, I would like to point out that in my opinion, Robert Litwiński’s work on General Kordian Józef Zamorski is an important and necessary book. First of all, it fills a gap in historiography. It is also based on a solid source query. Most of the conclusions drawn by the author are beyond doubt, too. What is more, Litwiński is very efficient in his use of the Polish language, which makes his work read very well. Moreover, the author enriched the content of the publication with quite a substantial illustrative material. Obviously, as I have shown in this review, there are some debatable elements however, they do not affect the substantive quality of the work. It seems to me, therefore, that Litwiński's book is worth looking at with a kind eye. 